\title{
Regeneration ability and genetic transformation of root type chicory (Cichorium intybus var. sativum)
}

\author{
Asad Maroufi $^{1 \star}$, Mansour Karimi ${ }^{2}$, Khosro Mehdikhanlou ${ }^{3,4}$, Erik Van Bockstaele ${ }^{3,4}$ and Marc \\ De Loose ${ }^{5,6}$
}

\footnotetext{
${ }^{1}$ Department of Agronomy and Plant Breeding, Faculty of Agriculture, University of Kurdistan, Sanandaj, Iran.

${ }^{2}$ VIB, Department of Plant Systems Biology, Gent University, VIB Research Building FSVM, Ghent, Belgium.

${ }^{3}$ Department of Plant production, Faculty of Bioscience Engineering, Gent University, Coupure links 653, 9000 Ghent, Belgium.

${ }^{4}$ Institute for Agricultural and Fisheries Research (ILVO), Plant Sciences Unit, Caritasstraat 21, 9090 Melle, Belgium.

${ }^{5}$ Department of Plant Biotechnology and Genetics, Faculty of Sciences, Gent University, K.L. Ledeganckstraat 35, 9000 Ghent, Belgium.

${ }^{6}$ Institute for Agricultural and Fisheries Research (ILVO), Burg Van Gansberghelaan 115 bus 1, 9820 Merelbeke, Belgium.
}

Accepted 28 May, 2012

To develop an efficient protocol for shoot regeneration of root chicory (Cichorium intybus var. sativum), some factors, including different concentrations of plant growth regulators in Murashige and Skoog (MS) medium, type of explants and genotypes were evaluated. Initiation of callusing were best achieved in MS medium supplemented with 1-naphthaleneacetic acid (NAA) $\left(0.1 \mathrm{mg} \mathrm{I}^{-1}\right)$ plus 6-Benzylaminopurine (6-BAP) (1 $\left.\mathrm{mg} \mathrm{I}^{-1}\right)$, indole-3-acetic acid (IAA) $\left(0.01 \mathrm{mg} \mathrm{l}^{-1}\right)$ plus 6-BAP $\left(1.0 \mathrm{mg} \mathrm{l}^{-1}\right)$, and IAA (0.5 $\left.\mathrm{mg} \mathrm{I}^{-1}\right)$ plus $\left(0.5 \mathrm{mg} \mathrm{l}^{-1}\right)$ 6-BAP combinations on leaf and cotyledon explants. Explant-derived calli were able to produce multiple adventitious shoots in MS medium containing IAA $\left(0.5 \mathrm{mg} \mathrm{l}^{-1}\right)$ plus 6-BAP $\left(0.5 \mathrm{mg} \mathrm{I}^{-1}\right)$. MS medium containing indole-3-butylric acid IBA $\left(1 \mathrm{mgl}^{-1}\right)$ efficiently induced rooting on elongated shoots. Various responses to the number of generated shoots were observed when regeneration abilities of different chicory cultivars were examined. Among root and "Witloof" cultivars, 'Melci' and 'Hera' belong to the root cultivars and exhibited higher shoot regeneration ability. Using the optimized regeneration method, genetic transformation of 'Melci' with Agrobacterium tumefaciens strain C58C1 Rif $^{\mathrm{f}}$ (pGV2260) (pTJK136) was successfully carried out. Histochemical GUS assay, polymerase chain reaction (PCR) and reverse transcription-polymerase chain reaction (RT-PCR) analysis of putative transformed plants confirmed successful integration of the T-DNA into the chicory genome. Expression of the neomycine phosphotransferase (NPTII) in the regenerated plants was also shown by welldeveloped roots on root inducing medium containing $100 \mathrm{mg} \mathrm{I}^{-1}$ kanamycin. This simple, efficient and reproducible protocol could be useful for inducing somaclonal variation and genetic modification of root chicory cultivars to broaden genetic variation and transferring of important genes.

Key words: Chicory, regeneration, transformation, 1-Naphthaleneacetic acid (NAA), indole-3-acetic acid (IAA), 6-Benzylaminopurine (6-BAP).

\section{INTRODUCTION}

Cichorium intybus var. sativum has been mostly

* Corresponding author. E-mail: a.maroufi@uok.ac.ir. Tel: 00988716620552 . Fax: 00988716620553. cultivated as a coffee substitute in Europe and also for the production of inulin used for food industry (Pazola, 1987; Langer et al., 1991; De Bruyn et al., 1992). "Witloof" chicory or "Belgian endive", perhaps the most known among the leafy chicories, is an important vegetable used as salad in Belgium, France and the 
Netherlands. The tuberous root of chicory contains a number of medicinally important compounds such as inulin, sesquiterpene lactones, coumarins, flavonoids and vitamins. Inulin, a polymer of fructose, is an important storage carbohydrate in some plants. Inulin has a wide range of applications in food and non-food industries because of its benefit for human health. Inulin is present in significant quantities in several fruits and vegetables, such as Jerusalem artichoke, salsify, asparagus, onion, garlic, dahlia and chicory (Nilsson et al., 1988; Silva, 1996; Rumessen et al., 1990; Van Loo et al., 1995), but the main source for commercial scale of inulin production is root chicory (Silva, 1996; De Leenheer, 1996). Although several cultivars of root chicory have been bred, it is desirable to breed new root chicory cultivars for high inulin content and resistance to herbicides, insects and pathogens. Classical breeding methods have been proved to be time-consuming and laborious. Agrobacterium-mediated plant transformation has been one of the preferred methods for genetic manipulation and rapid improvement of crops. However, the availability of an efficient regeneration protocol is a prerequisite for transformation of root chicory plants. Moreover, somaclonal variation is often induced by tissue culture conditions in differentiating vegetative cells (Larkin and Scowcroft, 1981; Muller et al., 1990). Somaclonal variation could be considered as one of the possible sources of inducing genetic variability to breeding programmes of root chicory plants. Some reports of regeneration in chicory do already exist (Lim et al., 2003; Rehman et al., 2003; Velayutham et al., 2007; Nandagopal and Ranjitha, 2007). However, most of the earlier studies were limited to specific varieties such as "Witloof" chicory and few experiments were carried out on the regeneration and genetic transformation of different root type chicory cultivars ( $C$ intybus $L$. var. sativum).

Transformation of Belgian endive has already been reported using Agrobacterium rhizogenesis (Sun et al., 1991). Vermeulen et al, (1992) successfully transferred Chlorsulfuron resistance through leaf disc transformation. NPTII combined with uidA genes, under the control of different promoters, were transferred either through tap root, cotyledon, and leaf disc explants (Abid et al., 1995). A transformation system, using Agrobacterium tumefaciens, has been developed for root chicory cultivars, using shoot bud as tissue explant and B5 (Gamborg) medium supplemented with $0.9 \mathrm{mM}$ BA (Frulleux et al., 1997). Fructosyltransferase gene from onion was transformed into chicory (Cichorium intybus), by using Agrobacterium-mediated leaf disk transformation to study synthesis of fructan of the inulin neoseries (Vijn et al., 1997). "Witloof" chicory (Cichorium intybus L. cv. Lucknow local), using Agrobacterium rhizogenes-mediated system, was stably transformed and the expression of transgene was confirmed (Harsh et al., 2001). The nodules derived from a "Witloof" Chicory cultivar were transformed with a $2.3 \mathrm{~kb}$ fragment of an apple calmodulin promoter region fused to the coding sequence of uidA reporter gene to study nodule morphogenesis in chicory leaves (Pieron and Watillon, 2001). Lol1 gene from over-wintering rye grass (Lolium perenne L.) which encodes a protein that inhibits the recrystallisation of ice was successfully introduced through Agrobacterium-mediated transformation into cotyledons excised from 17 days-old seedlings of "Witloof" chicory. cv. Brussels (Williams et al., 2003).

Therefore, we focus on the study of regeneration and transformation of recent commercially bred root type cultivars such as 'Melci' and 'Hera'. The effect of different combinations and concentrations of a number of plant growth regulators was assessed for their effect on callus induction or shoot regeneration on cotyledon and leaf explants. Since, an efficient and reliable regeneration in many plant species is affected by the genotype (Zhang et al., 1997; Khatun et al., 2003), therefore, to assess genotypic effect of different cultivars on frequency of regeneration in chicory, we compared the regeneration ability of ten different cultivars, including old and new root type, besides some already used "Witloof" cultivars. The results would be helpful in providing the optimum concentrations of plant growth regulators, genotype and explant source for further use in regeneration and transformation of chicory. It is well known that for an efficient Agrobacterium-mediated plant transformation, a reliable and efficient callus induction and shoot regeneration procedures are main concern. In this study we also presented the results of an Agrobacteriummediated transformation on cotyledon and leaf explants of 'Melci', a root chicory cultivar, using the optimised regeneration procedure to assess the efficiency of the developed system. The genetic transformation method can be used as a basis for the future development of commercial cultivars of root chicory plants.

\section{MATERIALS AND METHODS}

\section{Plant material and explant preparation}

In this experiment, root chicory (C. intybus var. sativum) and "Witloof" chicory (C. intybus var. foliosum) cultivars were used (Table 1). Seeds of the selected cultivars were surface-sterilised as follows. The seeds were immersed in $70 \%$ ethanol for 2 to $3 \mathrm{~min}$ then, they were rinsed five times in sterile distilled water. Next, the explants were incubated for $30 \mathrm{~min}$ in $10 \%(\mathrm{v} / \mathrm{v})$ sodium hypochlorite containing $0.5 \%$ Tween 20 . After rinsing five times with sterile distilled water, seeds were placed on semi-solidified germination medium (GM) (Table 2) in sterilised glass jars. Leaf and cotyledon pieces from three-week-old seedlings were used as explants for callus induction.

\section{Media recipes, callus induction, shoot and root organogenesis}

MS medium (Murashige and Skoog, 1962), including vitamins (Duchefa), was used in all experiments. Sucrose, appropriate plant 
Table 1. Different chicory cultivars used to compare regeneration ability.

\begin{tabular}{cl}
\hline Cultivar (V) & Name \\
\hline V1 & 'Melci' Root type (C. intybus var. sativum) cultivar \\
V2 & 'Hera' Root type (C. intybus var. sativum) cultivar \\
V3 & 'Nula' Root type (C. intybus var. sativum) cultivar \\
V4 & 'Tilda' Root type (C. intybus var. sativum) cultivar \\
V5 & 'Hicor' Root type (C. intybus var. sativum) cultivar \\
V6 & 'Bea' 'Witloof' type (C. intybus var. foliosum) cultivar \\
V7 & 'Zoom' (F1) 'Witloof' type (C. intybus var. foliosum) cultivar \\
V8 & 'Middelvroeg' 'Witloof' type $($ C. intybus var. foliosum) cultivar \\
V9 & 'Brussels' 'Witloof' type (C. intybus var. foliosum) cultivar \\
V10 & 'Focus' (F1) 'Witloof' type (C. intybus var. foliosum) cultivar \\
\hline
\end{tabular}

Table 2. Composition of various media with all additives used for different steps of chicory regeneration and transformation.

\begin{tabular}{lccccc}
\hline Medium & MS ( $\left.\mathbf{g ~ I}^{-1}\right)$ & Sucrose $\left(\mathbf{g ~ I}^{-1}\right)$ & Gelrite $\left(\mathbf{g ~ I}^{-1}\right)$ & Plant growth regulator & $\mathbf{p H}$ \\
\hline liquid medium & 4.4 & 20 & 3 & $\mathrm{M}_{1}$ & 5.8 \\
germination (GM) & 2.2 & 20 & 3 & - & 5.8 \\
co-cultivation & 4.4 & 20 & 3 & $\mathrm{M}_{1}$ & 5.8 \\
callus induction (CIM)/shoot induction (SIM) & 4.4 & 20 & 3 & $\mathrm{M}_{1}-\mathrm{M}_{12}$ & 5.8 \\
root induction (RIM) & 4.4 & 15 & 3 & $\mathrm{R}_{1}-\mathrm{R}_{9}$ & 5.8 \\
\hline
\end{tabular}

Table 3. Combination of different plant growth regulators used to make different media.

\begin{tabular}{|c|c|c|c|}
\hline $\begin{array}{l}\text { Code name } \\
\text { (treatment) }\end{array}$ & $\begin{array}{l}\text { Plant regulator combinations for } \\
\text { callus induction or shoot induction }\end{array}$ & $\begin{array}{l}\text { Code name } \\
\text { (treatment) }\end{array}$ & $\begin{array}{c}\text { Plant regulator combinations } \\
\text { for root induction }\end{array}$ \\
\hline $\mathrm{M}_{1}$ & $0.1 \mathrm{mg} \mathrm{I}^{-1} \mathrm{NAA}+1.0 \mathrm{mg} \mathrm{I}^{-1} 6-\mathrm{BAP}$ & $\mathrm{R}_{1}$ & $0.1 \mathrm{mg} \mathrm{I}^{-1} \mathrm{NAA}$ \\
\hline $\mathrm{M}_{2}$ & $0.5 \mathrm{mg} \mathrm{I}^{-1} \mathrm{NAA}+1.0 \mathrm{mg} \mathrm{I}^{-1} 6-\mathrm{BAP}$ & $\mathrm{R}_{2}$ & $0.5 \mathrm{mg} \mathrm{I}^{-1} \mathrm{NAA}$ \\
\hline$M_{3}$ & $0.1 \mathrm{mg} \mathrm{I}^{-1} \mathrm{IAA}+1.0 \mathrm{mg} \mathrm{I}^{-1} 6$-BAP & $\mathrm{R}_{3}$ & $1.0 \mathrm{mg} \mathrm{I}^{-1} \mathrm{NAA}$ \\
\hline $\mathrm{M}_{4}$ & $0.5 \mathrm{mg} \mathrm{I}^{-1} \mathrm{IAA}+1.0 \mathrm{mg} \mathrm{I}^{-1} 6-\mathrm{BAP}$ & $\mathrm{R}_{4}$ & $0.1 \mathrm{mg} \mathrm{I}^{-1} \mathrm{IAA}$ \\
\hline $\mathrm{M}_{5}$ & $0.1 \mathrm{mg} \mathrm{I}^{-1} \mathrm{NAA}+0.5 \mathrm{mg} \mathrm{l}^{-1} 6-\mathrm{BAP}$ & $\mathrm{R}_{5}$ & $0.5 \mathrm{mg} \mathrm{I}^{-1}$ IAA \\
\hline$M_{6}$ & $0.5 \mathrm{mg} \mathrm{l}^{-1} \mathrm{NAA}+0.5 \mathrm{mg} \mathrm{l}^{-1} 6-\mathrm{BAP}$ & $\mathrm{R}_{6}$ & $1.0 \mathrm{mg} \mathrm{I}^{-1} \mathrm{IAA}$ \\
\hline$M_{7}$ & $0.1 \mathrm{mg} \mathrm{l}^{-1} \mathrm{IAA}+0.5 \mathrm{mg} \mathrm{I}^{-1} 6-\mathrm{BAP}$ & $\mathrm{R}_{7}$ & $0.1 \mathrm{mg} \mathrm{I}^{-1} \mathrm{IBA}$ \\
\hline$M_{8}$ & $0.5 \mathrm{mg} \mathrm{l}^{-1} \mathrm{IAA}+0.5 \mathrm{mg} \mathrm{I}^{-1} 6-\mathrm{BAP}$ & $\mathrm{R}_{8}$ & $0.5 \mathrm{mg} \mathrm{I}^{-1} \mathrm{IBA}$ \\
\hline$M_{9}$ & $0.01 \mathrm{mg} \mathrm{l}^{-1} \mathrm{NAA}+1.0 \mathrm{mg} \mathrm{l}^{-1} 6-\mathrm{BAP}$ & $\mathrm{R}_{9}$ & $1.0 \mathrm{mg} \mathrm{I}^{-1} \mathrm{IBA}$ \\
\hline$M_{10}$ & $0.01 \mathrm{mg} \mathrm{I}^{-1} \mathrm{IAA}+1.0 \mathrm{mg} \mathrm{I}^{-1} 6-\mathrm{BAP}$ & & \\
\hline$M_{11}$ & $0.01 \mathrm{mg} \mathrm{l}^{-1} \mathrm{NAA}+0.5 \mathrm{mg} \mathrm{l}^{-1}$ 6-BAP & & \\
\hline $\mathrm{M}_{12}$ & $0.01 \mathrm{mgl}^{-1} \mathrm{IAA}+0.5 \mathrm{mgl}^{-1} 6-\mathrm{BAP}$ & & \\
\hline
\end{tabular}

growth regulators with different concentrations (Tables 2 and 3), and Gelrite (0.3\% w/v; Duchefa) as gelling agent, were added into media, and the $\mathrm{pH}$ of the media was adjusted to 5.8 using $\mathrm{KOH}$ before autoclaving. For transformation experiment, filter-sterilized antibiotics were added after autoclaving. The explants (leaf or cotyledon) were placed on callus induction medium (CIM) supplemented with $\mathrm{M}_{1}-\mathrm{M}_{12}$ (Table 3 ) to select appropriate combination of plant growth regulators in callus induction phase. Callus-derived explants from cotyledon or leaf pieces were also cultured on shoot induction medium (SIM), supplemented with $M_{1}$ $\mathrm{M}_{12}$ to select appropriate combination of plant growth regulators in shoot regeneration phase. In each phases of callus induction or shoot regeneration, a total of 18 explants were placed on each medium (three replicates, six explants on each replicate). The cultures were incubated at $24 \pm 2^{\circ} \mathrm{C}$ under $16 / 8 \mathrm{~h}$ (light/dark) photoperiod with white fluorescent lights, giving a photon flux density of 150 to $200 \mu \mathrm{M} \mathrm{m}^{-2} \mathrm{~s}^{-1}$, and relative humidity of 50 to $60 \%$. To select appropriate combination of plant growth regulators on root inducing, the regenerated shoots were excised from calli and transferred to the medium supplemented with root, inducing growth regulators $\left(R_{1}-R_{9}\right)$ (Table 3$) .16$ shoots were placed on each rooting medium. 


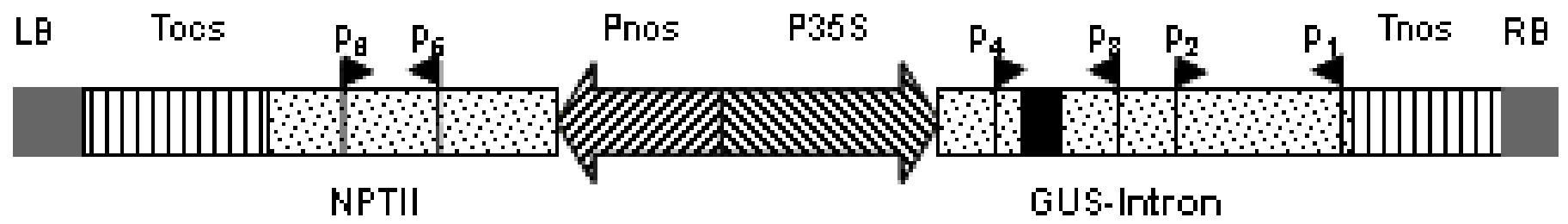

Figure 1. Schematic outline of T-DNA region of binary vector (pTJK136). RB, right border; Tocs, octopine synthase terminator; NPTII, neomycin phosphotransferase; Pnos, nopaline synthase promoter; P35S, CaMV 35S promoter; GUS-INT, $\beta$-glucuronidase interrupted by an intron; Tnos, nopaline synthase terminator; LB, left border; $p_{1}, p_{2}, p_{3}, p_{4}, p_{5}$ and $p_{6}$ designed primers to amplify different expected size by PCR. $p_{1}$ and $p_{2}$ amplify GUS1 expected size 866 bp, $p_{3}$ and $p_{4}$ amplify GUS2 expected size on cDNA 432 bp and on DNA 622 bp, $p_{5}$ and $\mathrm{p}_{6}$ amplify NPTII expected size $481 \mathrm{bp}$.

\section{Effect of chicory cultivars on shoot regeneration}

An experiment was set up, using optimised callus and shoot, inducing plant growth regulators $\left(\mathrm{M}_{1}\right.$ used for callus induction and $\mathrm{M}_{8}$ for shoot induction) to study the regeneration ability of different cultivars belonging to "Witloof" or root chicory (Table 1). A sample of leaf or cotyledon explants from each cultivar was incubated on MS media containing $M_{1}$ to produce explant-derived callus. The 20 explant-derived calli (four explants in five replicates) were then incubated on media containing $M_{8}$ to induce shoots. The numbers of produced shoots from leaf or cotyledon explant-derived calli of ten cultivars were eventually compared.

\section{Agrobacterium strain, plasmids and transformation}

Agrobacterium tumefaciens strain C58C1 Rif $^{\mathrm{R}}$ (pGV2260) (pTJK136) was provided by PSB, Ghent, Belgium. pGV2260 vector has the octopine-type vir genes (Deblaere et al., 1987). The pTJK136 binary vector in the T-DNA contains a $\beta$-glucouronidase (GUS) gene, under control of the cauliflower mosaic virus 35S RNA promoter (CaMV 35S) and NOS terminator and kanamycin resistance gene (neomycin phosphotransferase-II; NPTII) (Figure 1). The GUS reporter gene is interrupted by an intron originating from the potato st-ls1 gene and it has been demonstrated that intron spliced out in Arabidopsis, tobacco, poplar and bean (Vancanneyt et al., 1990; Kapila et al., 1997). The Agrobacterium was inoculated into a YEB medium (Vervuet et al., 1975) containing $50 \mathrm{mg} \mathrm{I}^{-1}$ rifampicin, $100 \mathrm{mg} \mathrm{I}^{-1}$ carbenicillin and $100 \mathrm{mg} \mathrm{I}^{-1}$ spectinomycin. The inoculated YEB medium was incubated at $28^{\circ} \mathrm{C}$ with reciprocal shaking (200 cycles/min) for $24 \mathrm{~h}$. The culture was transferred to a sterile $50 \mathrm{ml}$ tube, and then centrifuged at room temperature for $10 \mathrm{~min}$ at $3000 \mathrm{~g}$. After removing the supernatant, the pellet was gently resuspended in $100 \mathrm{ml}$ of sterile MS liquid medium (Table 2).

Cotyledon and leaf explants were prepared from 'Melci' 21-dayold seedlings. After wounding on the abaxial surfaces, they were immersed for $30 \mathrm{~min}$ in the infection medium, supplemented with 20 $\mathrm{mg} \mathrm{I}^{-1}$ acetosyringone and Agrobacterium strain (OD A600 nm $=0.6$ to 1.0). Cotyledon and leaf pieces were blotted dry on sterile filter paper and transferred to co-cultivation medium (Table 2) containing no antibiotics. Eight to ten cotyledon or leaf pieces were placed on co-cultivation medium in a $9 \mathrm{~cm}$ Petri dish. Co-cultivated explants were incubated for three days in growth chamber under $16 / 8 \mathrm{~h}$ (light/dark) photoperiod with white fluorescent lights, giving a photon flux density of 150 to $200 \mu \mathrm{M} \mathrm{m}^{-2} \mathrm{~s}^{-1}$ at a temperature of $24^{\circ} \mathrm{C} \pm 2$.

After co-cultivation, the explants were washed three times in sterilised liquid MS medium supplemented with $500 \mathrm{mg} \mathrm{I}^{-1}$ cefotaxime to counter selection of Agrobacterium cells. The explants were dried on sterilised-tissue paper and were transferred onto MS supplemented with $\mathrm{M}_{1}, 50 \mathrm{mg} \mathrm{l}^{-1}$ kanamycin and $500 \mathrm{mg}$ $I^{-1}$ cefotaxime. After callus induction, the explants were sub-cultured every two weeks on fresh MS containing $\mathrm{M}_{8}, 50 \mathrm{mg} \mathrm{I}^{-1}$ kanamycin and $500 \mathrm{mg} \mathrm{I}^{-1}$ cefotaxime until shoots appeared. Shoots $(<2 \mathrm{~cm}$ in height) were excised from regenerated explants and were individually transferred into $175 \mathrm{ml}$ glass jars containing MS supplemented with $\mathrm{R}_{9}\left(1 \mathrm{mg} \mathrm{^{-1 }}\right.$ IBA) (Table 3$)$. Concentration of kanamycin in the MS supplemented with $R_{9}$ was doubled (100 mg $\mathrm{I}^{-1}$ kanamycin) to increase the selection pressure. The rooted shoots were gently removed from root inducing medium and washed in liquid medium to clean the gelling pieces. The well developed complete plantlets were transferred into 10 to $15 \mathrm{~cm}$ pots containing sterilized-soil. Pots were covered with a perforated transparent plastic and placed in the growth chamber to acclimatize. After two to three days, plastic cover was opened from the top, and after one week, when the plants were strong enough, the transparent plastic cover was completely removed.

\section{Histochemical GUS assay}

At two different stages of development, including calli formation and well-developed leaf or tuberous root, histochemical GUS assay, according to the modified method of Jefferson (1987), was performed. The calli, leaf or root explants from the putative transgenic lines, and controls were immersed into the GUS staining solution, and vacuum infiltrated for $10 \mathrm{~min}$. The samples were wrapped in aluminium foil and incubated overnight at $37^{\circ} \mathrm{C}$. After staining, plant materials were washed three times in phosphate buffer and were fixed in $0.5 \%$ gluteraldehyde for $1 \mathrm{~h}$, and then they were kept in $70 \%$ ethanol to clear the chlorophyll. The GUS staining solution contained $38.3 \mathrm{mM}$ 5-bromo-4-chloro-3-indolyl- $\beta$-Dglucuronic acid (X-gluc), $12.5 \mathrm{mM}$ potassium hexacyanoferrate (II), $12.5 \mathrm{mM}$ potassium hexacyanoferrate (III) trihydrate, $0.3 \%$ Triton $\mathrm{X}$ 100 , and $150 \mathrm{mM}$ sodium phosphate ( $\mathrm{pH} 7.0)$.

\section{DNA isolation and the polymerase chain reaction (PCR)}

Genomic DNA was isolated from leaves of the putative transgenic and non-transgenic (control) root chicory plants using the DNeasy Plant Mini kit according to the manufacturer's instructions (Qiagen). Concentration of total DNA was measured using a Nanodrop ND1000 spectrophotometer (Thermo SCIENTIFIC). The PCR reaction was done with the final volume of $50 \mu \mathrm{L}$ that contained: 100 to $200 \mathrm{ng}$ of plant DNA, 15 pmol of each primer (Table 4), 200 $\mu \mathrm{M}$ dNTPs mix, 5 ul PCR buffer $5 x$ and 1 unit Taq DNA polymerase (AmpliTaq-Applied Biosystems) and autoclaved millipore water. The PCR was completed, using a thermocycler (Applied Biosystems) with the following conditions; 2 min at $95^{\circ} \mathrm{C}$, followed by 35 cycles 
Table 4. Selected amplicons for PCR or RT-PCR analysis.

\begin{tabular}{ccllcc}
\hline Name amplicon & Size $(\mathbf{b p})$ & Forward primer & Reverse primer & PCR & RT-PCR \\
\hline GUS1 & 866 & CGTGGCAAAGGATTCGATAA & ATGCCAGTCCAGCGTTTTT & + & \\
GUS2 & 422 & TTCGATGCGGTCACTCATTA & GCTAGTGCCTTGTCCAGTT & & + \\
NPTII & 481 & AGCGGCGATACCGTAAAGCACGA & AAGGGACTGGCTGCTATTGGC & + & + \\
\hline
\end{tabular}

of denaturation for $30 \mathrm{~s}$ at $94^{\circ} \mathrm{C}$, annealing for $30 \mathrm{~s}$ (various temperature) and extension at $72^{\circ} \mathrm{C}(60 \mathrm{~s}$ per $\mathrm{kb})$ and ending with 7 min at $72^{\circ} \mathrm{C}$ for final extension. The PCR amplified products along with DNA ladder (Fermentas) were separated by electrophoresis in a $1.2 \%$ agarose gel in TAE buffer, stained with ethidium bromide, and visualized under ultraviolet light.

\section{RNA isolation and RT-PCR}

Total RNA was isolated from leaf tissues of putative transgenic plants using RNeasy Plant mini kit according to the manufacturer's instructions (Qiagen). RNA was treated with RNase-free DNase, and the DNase removed according to the manufacturer's instructions (Ambion). RNA was quantified using a Nanodrop ND1000 spectrophotometer (Thermo SCIENTIFIC). cDNA was synthesized from $500 \mathrm{ng}$ total RNA, using SuperScript ${ }^{\mathrm{TM}}$ III Reverse Transcriptase (Invitrogen) following company's instructions. $1 \mu \mathrm{l}$ of the first cDNA strand solution, using a specific primer flanked intron region (Figure1 and Table 4) was used for each PCR reaction as described above. The PCR amplified products, along with DNA ladder (Fermentas), were separated by electrophoresis in a 1.2\% agarose gel in TAE buffer, stained with ethidium bromide, and visualized under ultraviolet light.

\section{Statistical analysis}

The experiments were set up in a completely randomised design. Data were recorded on the total number of shoots. All data were transformed to satisfy the assumption of normality prior to analysis of variance. Means and standard errors were obtained from analysis for each treatment. The means of the induced shoots were compared using Duncan's multiple range test at a $1 \%$ probability level.

\section{RESULTS}

\section{Effect of plant growth regulators on callus induction}

The effect of different combinations and concentrations of the selected plant growth regulators (Table 3 ) on callus induction from cotyledon or leaf explant of 'Melci' and 'Hera' were investigated. Calli got initiated after two weeks of culture, both for cotyledon or leaf explants on MS medium supplemented with all combinations of NAA or IAA plus 6-BAP. In the callus induction phase, cells on the cutting edge of the explants start to form callus in response to the plant growth regulators. All formed-calli had a round shape and seem to be non-embryogenic. The formed-calli on different combinations of plant growth regulators varied in colour and regenerative capacity (Figure 2 and Table 5). In general, some combinations such as $M_{1}, M_{2}, M_{4}, M_{8}$, and $M_{10}$ could induce green calli with high biomass for both types of explants. However, compact and green, with maximum regenerative callus biomass were induced by leaf explants in MS supplemented with $M_{1}, M_{8}$, and $M_{10}$ combinations, and very good green calli with high regenerative callus were also formed by cotyledon explants with $M_{1}, M_{8}$, and $M_{10}$ combinations (Figure 2 and Table 5). In addition, leaf explants in most of the combinations were more responsive than cotyledon explants in terms of callus induction such as in the $M_{1}, M_{2}, M_{3}, M_{4}, M_{7}, M_{8}$ and $M_{10}$ combinations (Figure 2).

\section{Effect of plant growth regulators on shoot organogenesis}

The effect of various combinations of plant growth regulators (Table 3 ) on shoot regeneration from cotyledon and leaf explant-derived calli of the cultivars 'Melci' and 'Hera' were investigated. Shoot buds were visible after three weeks of culture and the number of produced shoots was recorded after six weeks. Since all media containing a plant growth regulator formulation could induce shoots in all leaf or cotyledon explantderived calli, the evaluation of shoot induction was based on the number of shoots for each plant growth regulator combination (treatment). The frequency of adventitious shoot regeneration differed, depending on the explants, genotypes and concentration of different growth regulators added to the media. Analysis of variance per treatment on the number of produced shoots from leaf or cotyledon explants of 'Melci' or 'Hera' were separately carried out. F-values for all analyses on the number of induced shoots from leaf and cotyledon explants of 'Melci' or 'Hera' were significant. Therefore, it can be concluded that significant differences existed between the combinations of growth regulators in the function of the number of generated shoots.

The " $\mathrm{M}_{8}$ " combination showed the highest number of induced shoot on leaf or cotyledon derived-calli explants for 'Melci' and 'Hera' cultivars. In all Duncan test, $\mathrm{M}_{8}$ combination stayed in group $A$, with the highest mean for number of regenerated shoots (Tables 6 and 7). In addition, $M_{7}$ and $M_{11}$ combinations showed high effect on the number of generated shoots. $M_{2}, M_{4}, M_{6}$ and $M_{12}$ were the least effective combinations for inducing shoot. Except $M_{7}$ and $M_{8}$, all combinations regenerated some vitrified shoots. Additionally, leaf explant-derived calli 

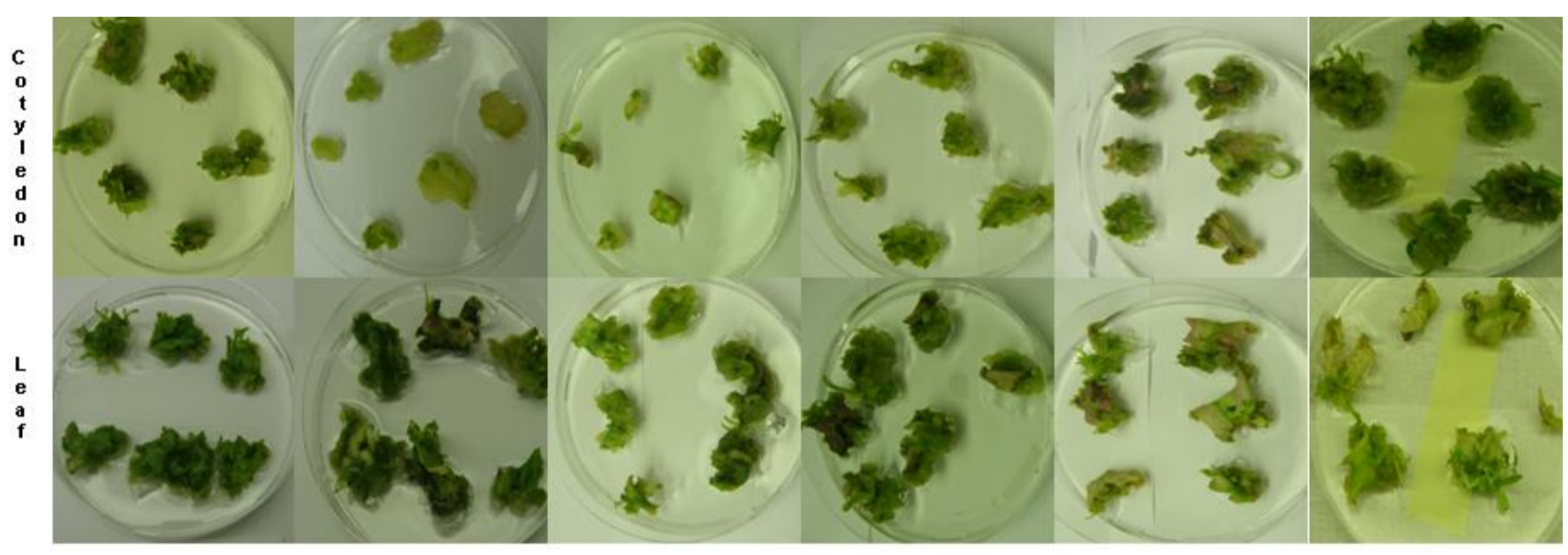

M1

M2

M3

M4

M5

M6

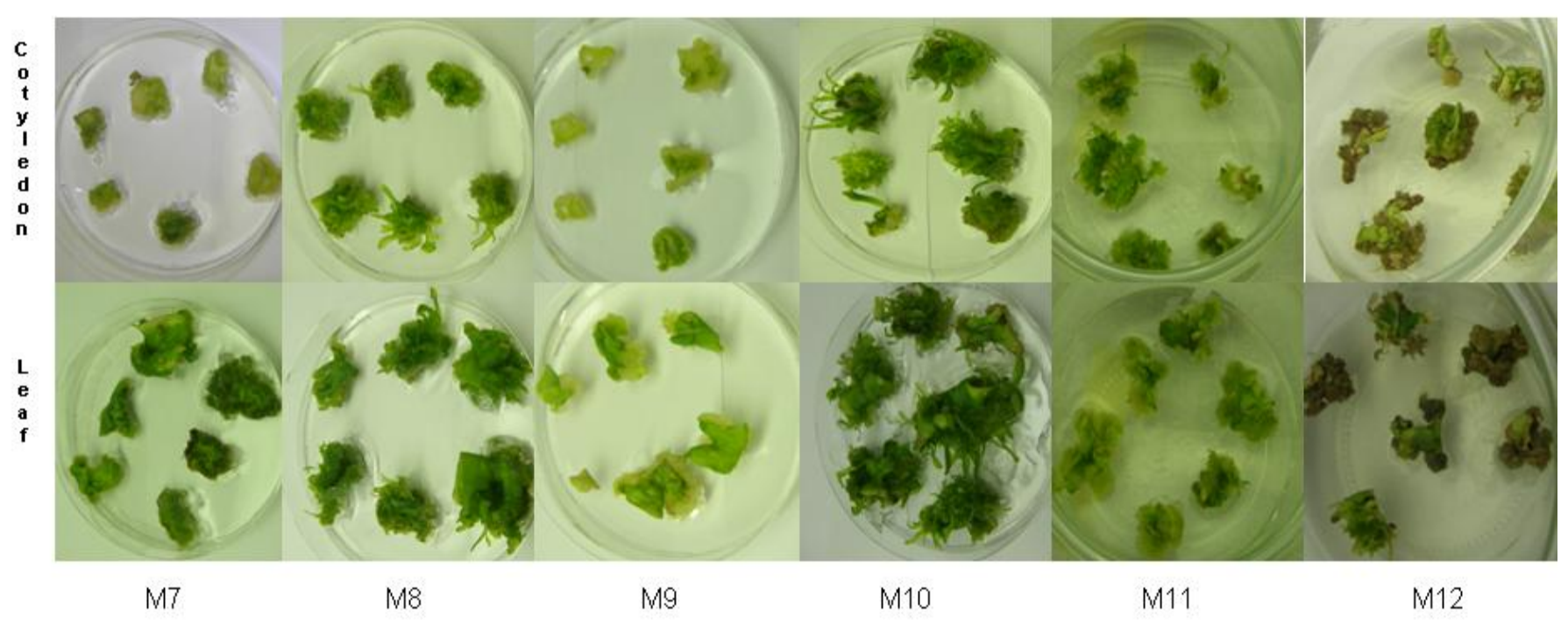

Figure 2. Effect of various plant growth regulators $\left(M_{1}-M_{12}\right)$ on callus induction of cotyledon and leaf explants.

Table 5. Effect of different regulators on callus induction in cotyledon and leaf explants of 'Melci'.

\begin{tabular}{cclcl}
\hline Treatment & $\begin{array}{c}\text { Quality of calli formed on } \\
\text { 'Melci' cotyledon explants }\end{array}$ & $\begin{array}{l}\text { Color of calli formed on } \\
\text { 'Melci' cotyledon explants }\end{array}$ & $\begin{array}{c}\text { Quality of calli formed } \\
\text { on 'Melci' leaf explants }\end{array}$ & $\begin{array}{l}\text { Color of calli formed on } \\
\text { 'Melci' leaf explants }\end{array}$ \\
\hline$M_{1}$ & +++ & green & ++++ & green \\
$M_{2}$ & + & yellow & +++ & green \\
$M_{3}$ & + & white to yellow & ++ & light green \\
$M_{4}$ & ++ & light green & +++ & green \\
$M_{5}$ & + & brownish-green & + & green to white \\
$M_{6}$ & +++ & green & + & yellow to brown \\
$M_{7}$ & + & white to yellow & ++ & green \\
$M_{8}$ & +++ & green & ++++ & green \\
$M_{9}$ & + & white to yellow & ++ & white to yellow \\
$M_{10}$ & +++ & green & ++++ & green \\
$M_{11}$ & ++ & yellow to green & ++ & yellow \\
$M_{12}$ & + & brown & + & brown \\
\hline
\end{tabular}

$+=$ weak callus $;++=$ good callus $;+++=$ very good callus $;++++=$ compact callus. 
Table 6. Means* comparison for 'Melci' explant-induced shoots on different plant regulator combinations (treatment; see Table 3).

\begin{tabular}{ccccc}
\hline Treatment & $\begin{array}{c}\text { Mean number of shoots induced on } \\
\text { 'Melci' cotyledon explant }\end{array}$ & $\begin{array}{c}\text { Duncan } \\
\text { grouping }\end{array}$ & $\begin{array}{c}\text { Mean number of shoots induced on } \\
\text { 'Melci' leaf explant }\end{array}$ & $\begin{array}{c}\text { Duncan } \\
\text { grouping }\end{array}$ \\
\hline$M_{1}$ & 7.66 & $\mathrm{C}$ & 10.66 & $\mathrm{~B}$ \\
$\mathrm{M}_{2}$ & 2.33 & $\mathrm{E} \mathrm{D}$ & 3 & $\mathrm{D}$ \\
$\mathrm{M}_{3}$ & 8.33 & $\mathrm{C}$ & 8.33 & $\mathrm{C}$ \\
$\mathrm{M}_{4}$ & 0.66 & $\mathrm{E} \mathrm{D}$ & 3 & $\mathrm{D}$ \\
$\mathrm{M}_{5}$ & 7 & $\mathrm{C}$ & 10.33 & $\mathrm{~B}$ \\
$\mathrm{M}_{6}$ & 1.66 & $\mathrm{D}$ & 2.66 & $\mathrm{D}$ \\
$\mathrm{M}_{7}$ & 14 & $\mathrm{~B}$ & 14.33 & $\mathrm{~B}$ \\
$\mathrm{M}_{8}$ & 28.33 & $\mathrm{~A}$ & 41.66 & $\mathrm{~A}$ \\
$\mathrm{M}_{9}$ & 8.66 & $\mathrm{C}$ & 13.33 & $\mathrm{~B}$ \\
$\mathrm{M}_{10}$ & 6.66 & $\mathrm{C}$ & 4.33 & $\mathrm{D}$ \\
$\mathrm{M}_{11}$ & 11 & $\mathrm{C} \mathrm{B}$ & 13.33 & $\mathrm{~B}$ \\
$\mathrm{M}_{12}$ & 2.66 & $\mathrm{D}$ & 4 & $\mathrm{D}$ \\
Total mean & 8.25 & & 10.74 & \\
\hline
\end{tabular}

*Means with the same letter are not significantly different.

Table 7. Means* comparison for 'Hera' explant-induced shoots on different plant regulator combinations (treatment; see Table 3).

\begin{tabular}{ccccc}
\hline Treatment & $\begin{array}{c}\text { Mean number of shoots induced on } \\
\text { 'Hera' cotyledon explant }\end{array}$ & $\begin{array}{c}\text { Duncan } \\
\text { grouping }\end{array}$ & $\begin{array}{c}\text { Mean number of shoots induced on } \\
\text { 'Hera' leaf explant }\end{array}$ & $\begin{array}{c}\text { Duncan } \\
\text { grouping }\end{array}$ \\
\hline$M_{1}$ & 6.33 & $\mathrm{C} \mathrm{D}$ & 8.66 & $\mathrm{CDE}$ \\
$\mathrm{M}_{2}$ & 1.66 & $\mathrm{E}$ & 4 & $\mathrm{G}$ \\
$\mathrm{M}_{3}$ & 6.33 & $\mathrm{C} \mathrm{D}$ & 7.66 & $\mathrm{DEF}$ \\
$\mathrm{M}_{4}$ & 2.66 & $\mathrm{E}$ & 4.66 & $\mathrm{~F} \mathrm{G}$ \\
$\mathrm{M}_{5}$ & 8 & $\mathrm{C} \mathrm{B} \mathrm{D}$ & 9 & $\mathrm{C} \mathrm{D} \mathrm{E}$ \\
$\mathrm{M}_{6}$ & 2.33 & $\mathrm{E}$ & 3.66 & $\mathrm{G}$ \\
$\mathrm{M}_{7}$ & 11.66 & $\mathrm{~B}$ & 15 & $\mathrm{~B}$ \\
$\mathrm{M}_{8}$ & 24 & $\mathrm{~A}$ & 39.33 & $\mathrm{~A}$ \\
$\mathrm{M}_{9}$ & 5.66 & $\mathrm{D}$ & 10.66 & $\mathrm{C} \mathrm{B} \mathrm{D}$ \\
$\mathrm{M}_{10}$ & 8 & $\mathrm{CB} \mathrm{D}$ & 6 & $\mathrm{EF} \mathrm{G}$ \\
$\mathrm{M}_{11}$ & 10 & $\mathrm{C} \mathrm{B}$ & 13 & $\mathrm{C} \mathrm{B}$ \\
$M_{12}$ & 1.33 & $\mathrm{E}$ & 3.66 & $\mathrm{G}$ \\
Total mean & 7.33 & & 10.44 & \\
\hline
\end{tabular}

*Means with the same letter are not significantly different.

could produce more shoots than cotyledon-derived calli (30\% for 'Melci' and $42 \%$ for 'Hera') (Tables 6 and 7 ).

\section{Effect of plant growth regulators on root organogenesis}

The excised-shoots from calli started root formation after one week on all root inducing medium combinations, except for $R_{2}$ and $R_{3}$ (Table 3 ). After three weeks of culture, it was found that among the three tested auxins, IBA was the best inducing rooting plant growth regulator in comparison with IAA or NAA. Higher frequency of root induction was obtained in MS medium supplemented with $\mathrm{R}_{9}$ combination (Table 8 ). Root length varied within each treatment (Table 8). MS medium supplemented with NAA produced thick and short roots. Roots in the media containing IAA and IBA were thin and with abundant hairlike secondary roots. Maximum root length was observed in MS supplemented with $\mathrm{R}_{7}$ (Table 8).

\section{Effect of chicory cultivars on shoot regeneration}

From high regeneration ability for 'Melci' and 'Hera' cultivars during optimization of the regeneration, we were 
Table 8. Effect of different auxins used to root induction.

\begin{tabular}{cccc}
\hline Treatment & $\mathbf{T}_{\mathbf{1}}{ }^{\boldsymbol{}}$ & $\mathbf{T}_{\mathbf{2}}{ }^{\boldsymbol{}}$ & Root length after three week \\
\hline $\mathrm{R}_{1}$ & 4 & 8 & $1 \mathrm{~cm}$ \\
$\mathrm{R}_{2}$ & 0 & 4 & $\leq 1 \mathrm{~cm}$ \\
$\mathrm{R}_{3}$ & 0 & 2 & $0.5 \leq$ \\
$\mathrm{R}_{4}$ & 9 & 12 & $>2$ \\
$\mathrm{R}_{5}$ & 6 & 7 & $2 \mathrm{~cm}$ \\
$\mathrm{R}_{6}$ & 3 & 5 & $1.5-2 \mathrm{~cm}$ \\
$\mathrm{R}_{7}$ & 6 & 14 & $>3$ \\
$\mathrm{R}_{8}$ & 7 & 13 & $2 \mathrm{~cm}$ \\
$\mathrm{R}_{9}$ & 10 & 16 & $1 \mathrm{~cm}$ \\
\hline
\end{tabular}

$T_{1}$ and $T_{2}$, number of shoots induced root after one week and after three weeks, respectively.

Table 9. Comparison of means* on number of induced-shoots from cotyledon and leaf derived callus of different chicory cultivars.

\begin{tabular}{ccccc}
\hline Cultivar & $\begin{array}{c}\text { Mean number of shoots induced } \\
\text { on cotyledon derived calli }\end{array}$ & $\begin{array}{c}\text { Duncan } \\
\text { Grouping }\end{array}$ & $\begin{array}{c}\text { Mean number of shoots } \\
\text { induced on leaf derived calli }\end{array}$ & $\begin{array}{c}\text { Duncan } \\
\text { Grouping }\end{array}$ \\
\hline V1 & 10 & $\mathrm{~A}$ & 15 & $\mathrm{~A}$ \\
V2 & 10 & $\mathrm{~A}$ & 14.6 & $\mathrm{~A}$ \\
V3 & 2.2 & $\mathrm{D}$ & 8.2 & $\mathrm{CB}$ \\
V4 & 2.2 & $\mathrm{D}$ & 6.6 & $\mathrm{C}$ \\
V5 & 3.6 & $\mathrm{CD}$ & 7 & $\mathrm{C}$ \\
V6 & 4.8 & $\mathrm{CB}$ & 9.4 & $\mathrm{CB}$ \\
V7 & 7 & $\mathrm{~B}$ & 9.2 & $\mathrm{CB}$ \\
V8 & 5.6 & $\mathrm{~B}$ & 8.4 & $\mathrm{CB}$ \\
V9 & 7.2 & $\mathrm{~B}$ & 11.2 & $\mathrm{~B}$ \\
V10 & 10.2 & $\mathrm{~A}$ & 11 & $\mathrm{~B}$ \\
Total mean & 6.27 & & 10.06 & \\
\hline
\end{tabular}

${ }^{*}$ Means with the same letter are not significantly different.

interested to compare regeneration abilities of those cultivars with some "Witloof" chicory cultivars which have been used in earlier regeneration and transformation experiments. In this experiment, in callus induction phase, explants started to produce calli after two weeks incubation on MS medium supplemented with $M_{1}$. Developed calli were then transferred to MS medium supplemented with $M_{8}$. Regenerated shoots in each replicate were counted for all cultivars after six weeks. Analysis of variance on the number of shoots was done using a completely randomised design. Comparisons of means by the Duncan multiple range test $(p<0.01)$ on the number of induced shoots from leaf-derived calli revealed that the cultivars 'Melci' and 'Hera' had the highest mean and they were grouped in 'A' (Table 9). The 'Focus' and 'Brussels' belonging to "Witloof" cultivars were grouped in ' $\mathrm{B}$ ', meaning high shoot regeneration ability. Additionally, the cultivars 'Focus', 'Melci' and 'Hera' were grouped in ' $A$ ' by the Duncan multiple range test $(p<0.01)$ for the number of induced shoots from cotyledon-derived calli explants (Table 9). 'Melci' and 'Hera' for both type of explants showed the highest regeneration capacity. In general, shoot regeneration ability calculated for the entire cultivars for calli derived from leaf was $60 \%$ higher than calli derived from cotyledon (Table 9).

\section{Agrobacterium-mediated transformation}

Calli produced on MS containing $M_{1}$, shoots appeared from calli after three to four weeks incubation on MS containing $\mathrm{M}_{8}, 50 \mathrm{mg} \mathrm{I}^{-1}$ kanamycin, and $500 \mathrm{mg} \mathrm{I}^{-1}$ cefotaxime. The regenerated shoots were excised at the base, and transferred to MS supplemented with $R_{9}$ for rooting. Shoots mostly were generated roots from cutting surface of the shoots after three weeks. The plantlets with well-developed root were then transferred to pots for further growth and analysis. Along the transformation experiment, a few non Agrobacterium-infected explants 

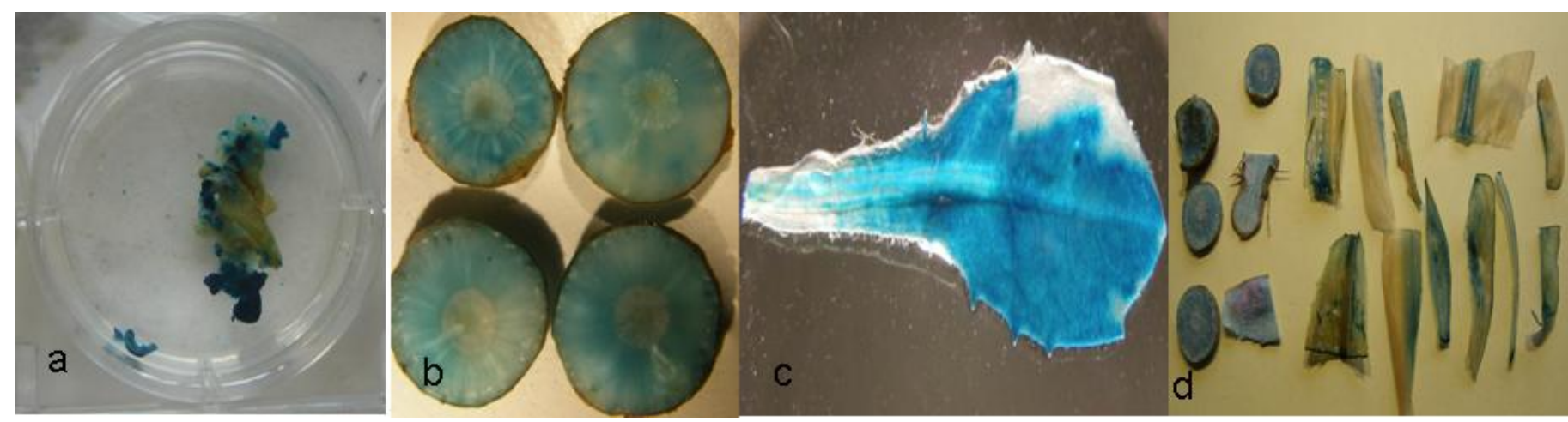

Figure 3. Overview of GUS staining at different developmental stages and tissues. (a) GUS staining on three-week-old calli. (b) GUS staining in tuberous root. (c) GUS staining in leaf. (d) Different response to GUS staining in different plant tissues.

were put on callus inducing medium containing kanamycin as control. All control explants got brownish and died. In total, 200 explants were inoculated and incubated on callus inducing medium. Eventually, following transformation and regeneration, 32 plantlets were selected. This represents a transformation frequency of about $16 \%$.

\section{Histochemical GUS assay}

To be able to monitor transformation, a histochemical GUS assay was performed after inoculation of the explants with the Agrobacterium strain. Un-inoculated explants were used as control. The generated calli stained positively for GUS assay (Figure 3a), while none of the controls stained positively with the X-gluc substrate. Additionally, leaf and root explants from the regenerated plants after transformation were tested for the histochemical GUS assay. Positive staining was found on leaf and root tissues (Figure $3 b$ and $c$ ). However, the intensities of GUS staining for the studied samples were different (Figure 3d), while the controls showed no staining reaction.

\section{Molecular analysis of transformant plants}

The PCR was used to verify the presence of the T-DNA in the selected putative transgenic plants, using specific primers for the GUS and NPTII amplicons (Figure 1 and Table 4). The presence of GUS and NPTII were confirmed by amplification of the expected 866 bp (base pair) and $481 \mathrm{bp}$ fragments, using specific primers, respectively (Table 4 , Figure $4 a$ and b). For all putative transgenic plants, a fragment of 422 bp was amplified using GUS2 primer pairs with RT-PCR (Figure 4c and Table 4). This confirms the presence of transgenes in the selected putative transformants. A fragment of $632 \mathrm{bp}$ would have been obtained if no splicing occurred or genomic DNA was used as template for PCR (Figure 4c).

\section{DISCUSSION}

Callus induction and shoot regeneration are in vitro tissue culture methods, which depend on environmental conditions and plant growth regulators. Optimisation of these factors is essential to establish a high frequency of callus induction and shoot regeneration. Plant growth regulators and types of explant are the most important factors for callus induction and shoot regeneration phases (Mineo, 1990). Transformation, by means of Agrobacterium-mediated or direct gene transfer methods is a widely-used technique for genetic improvement of crops (de la Riva, 1998). The transformation techniques are essentially based on callus formation and regeneration of transformed calli. Additionally, to improve crops using somaclonal variation and in vitro selection, an efficient method of shoot regeneration from calli is necessary. Therefore the important described issues were studied to generate an optimised protocol for regeneration and transformation of root chicory plants.

The application of different concentrations of plant growth regulators had a significant influence on callus development and organogenesis. The data showed the response of explants to form calli, and was seen within two weeks incubation on callus-inducing medium containing different plant growth regulators for both 'Melci' and 'Hera' cultivars. The same observation on the period of callus induction was reported by Nandagopal and Ranjitha (2007). The combinations of IAA or NAA with 6-BAP showed a positive effect on cell division for both leaf and cotyledon explants in root chicory (Figure 2). Leaf or cotyledon explants were able to form calli, but the qualities of produced calli were different. Calli were formed, going from weak to very compact type, in the presence of NAA or IAA, with combination of 6-BAP. Combinations of $0.1 \mathrm{mg} \mathrm{I}^{-1} \mathrm{NAA}+1.0 \mathrm{mg} \mathrm{I}^{-1}$ 6-BAP, 0.5 $\mathrm{mg} \mathrm{l}^{-1} \mathrm{IAA}+0.5 \mathrm{mg} \mathrm{I}^{-1}$ 6-BAP; and $0.01 \mathrm{mg} \mathrm{I}^{-1} \mathrm{IAA}+1.0$ $\mathrm{mg} \mathrm{I}^{-1} 6$-BAP induced the highest callus formation inboth leaf and cotyledon explants.

Yucesan et al. (2007) reported that NAA alone or in 


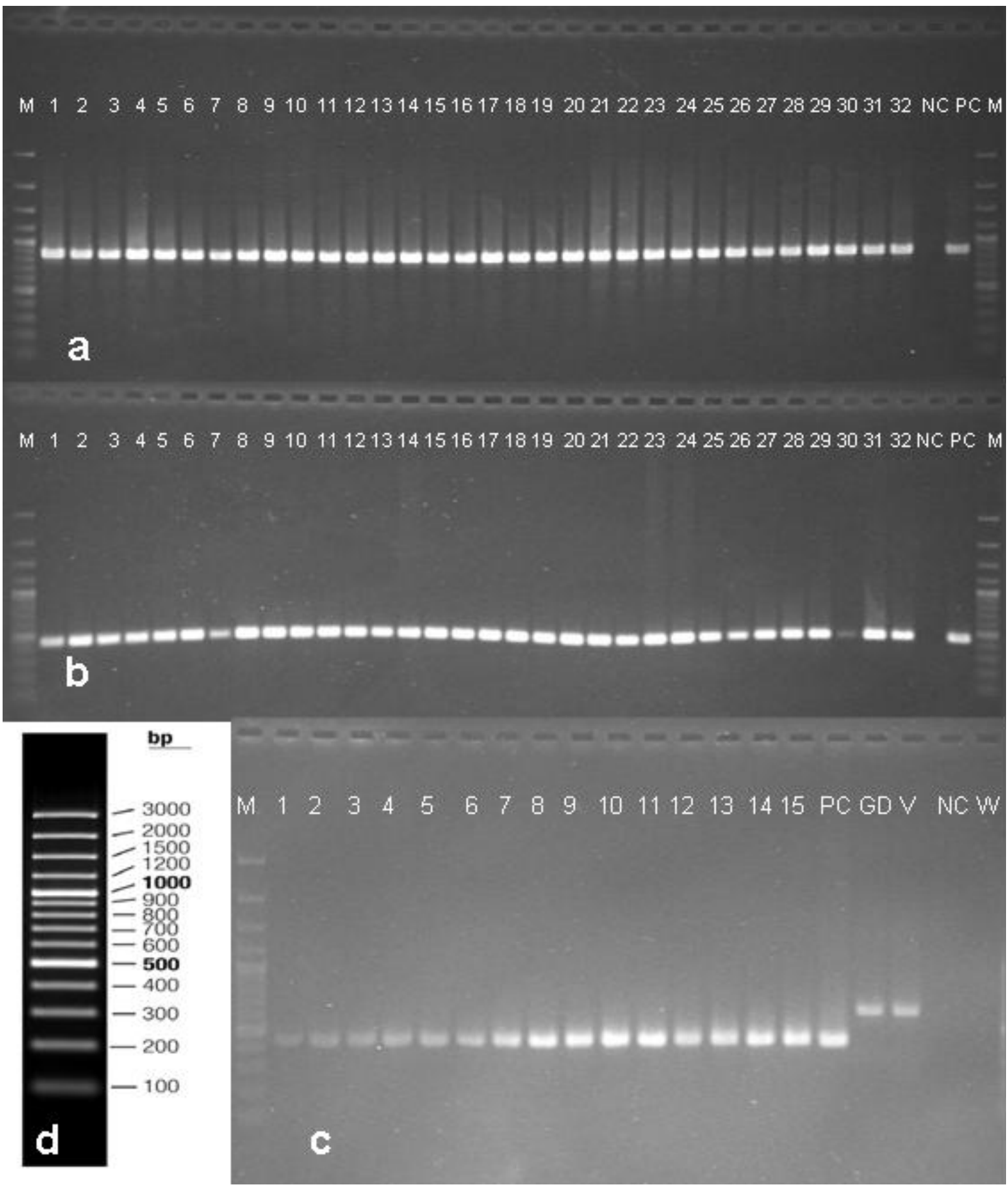

Figure 4. PCR and RT-PCR to detect transgenic plants.(a) A 866 bp fragment from the GUS coding sequence was amplified from DNA isolated from 32 different selected plants using GUS1 primer pairs $\left(p_{1}\right.$ and $p_{2}$ in Figure 1 and Table 4). (b) A $481 \mathrm{bp}$ fragment from the NPTII was amplified from DNA isolated from 32 different selected plants using NPTII primer pairs ( $p_{5}$ and $p_{6}$ in Figure 1 and Table 4); (c) A 432 bp fragment from cDNA of 15 selected transformed plants was amplified using GUS2 primer pairs $\left(p_{3}\right.$ and $p_{4}$ in Figure 1 and Table 4$)$; (d) Indicates molecular marker (M) (GeneRuler ${ }^{\mathrm{TM}} 100 \mathrm{bp}$ Plus DNA Ladder, Fermentas). Regenerated plants are indicated as numbers on the lanes; $\mathrm{NC}=$ negative control (non-transgenic plant); PC = positive control (vector pTtjk136); GD = genomic DNA from transgenic plant; $\mathrm{V}=$ vector $\mathrm{pTJK} 136 ; \mathrm{W}=$ water.

combination with 6-BAP produced considerably more callus with green-to-yellowish and highly friable callus.
Velayutham et al., (2007) reported that a higher frequency of callus was observed on MS medium 
supplemented with NAA $\left(1.86 \mathrm{mg} \mathrm{l}^{-1}\right)$ in combination with BAP $\left(0.45 \mathrm{mg} \mathrm{l}^{-1}\right)$. Although, they also used combinations of IAA with 6- BAP, but this combination with different concentration was not an efficient formula for callus induction in their study. However, Nandagopal and Ranjitha (2006) obtained maximum callusing for 'Focus', a cultivar belonging to "Witloof" on a combination of 6 BAP $\left(1.5 \mathrm{mg} \mathrm{l}^{-1}\right)$ with IAA $\left(0.5 \mathrm{mg} \mathrm{I}^{-1}\right)$.

Shape of formed calli was globular on callus inducing phase, and shoots were directly induced from calli. The same observations were reported by Wagner and Gailing (1996), Rehman et al. (2003) and Velayutham et al., (2007). In shoot inducing phase, shoots were produced within three to four weeks. The number of induced-shoots was found to vary in the different combinations of 6-BAP plus IAA or NAA. High promotion of shoot regeneration in the presence of 6-BAP plus IAA in this study is compatible with several reports for different chicory cultivars by Park and Lim (1999), Velayutham et al., (2007), Nandagopal and Ranjitha (2006) and Yucesan et al. (2007). Multiple shoots and the highest shoot regeneration frequency were obtained with callus from leaf or cotyledon explants on MS medium containing 0.5 $\mathrm{mg} \mathrm{l}^{-1} 6$-BAP plus $0.5 \mathrm{mg} \mathrm{l}^{-1}$ IAA $\left(\mathrm{M}_{8}\right)$. Other combinations such as $M_{3}, M_{5}, M_{10}$ and $M_{11}$ induced multiple shoots but a number of shoots were vitrified. Eventually, applying different concentrations of plant growth regulators had significantly different influence on frequency of produced shoots (Table 6 and 7). In this study, the best regeneration rate was found from leaf-derived-calli explant. Moreover, among three different tested auxins, IBA (1 mg $\left.~^{-1}\right)$ was found to be more efficient plant growth regulators on root initiation. IBA was also reported as the most efficient rooting plant growth regulator for "Witloof" cultivars by Rehman et al. (2003), Velayutham et al., (2007) and Nandagopal and Ranjitha (2007).

In shoot regeneration abilities of different cultivars, we used MS containing $M_{1}$ combination for inducing callus to equally treat both cotyledon or leaf explants for all ten cultivars, then the derived-calli explants were cultured on MS containing $M_{8}$ combination to induce shoot. The regeneration rates according to the number of produced shoots varied between leaf and cotyledon explants for each cultivar. Leaf explants showed better performance to shoot regeneration. In addition, our result indicate that 'Melci' and 'Hera' cultivars from the root varieties produced the highest number of shoots, indicating higher shoot regeneration capacity. Therefore, the regeneration frequencies are greatly influenced by the type of cultivar. The 'Melci' and 'Hera' cultivars had good ability to vegetatively multiply mature root pieces (Joost Baert, ILVO, Belgium). It might be that the clones, which have been selected for the final polycross to build up 'Melci' and 'Hera' cultivars in breeding programmes, were indirectly selected for great regeneration capacity addition to high inulin yield, no bolting and resistance to diseases. In contrast, this may not be the case for old
"Witloof" chicory. This could be one possible reason for better regeneration ability of these two root type chicory genotypes. Park and Lim (1999) also reported that 'Guilio', a cultivar belonging to var, sativum, was found to be the best genotype among a number of investigated genotypes for shoot regeneration capacity. These findings support that the different genetic backgrounds might have an impact on the regeneration capacity in chicory as it was also reported for other plant species (Zhang et al., 1997; Khatun et al., 2003). Therefore, it can be concluded that regeneration frequencies in chicory were greatly influenced by the cultivar.

Furthermore, transformation of 'Melci' was successfully achieved by applying the Agrobacterium-mediated gene transfer technology. The regeneration protocol of the present study was used for transformation to generate transgenic root chicory plants. The results confirmed the successful callus formation, shoot and root organogenesis through leaf and cotyledon explants during transformation of root chicory. To avoid development of undesirable number of escapes, kanamycin was increased from 50 to $100 \mathrm{mg} \mathrm{l}^{-1}$ in root inducing medium. There was no negative effect on rooting in comparison with controls. Draper et al., (1988) demonstrated that roots are generally much more sensitive to antibiotics; therefore the root induction on medium containing high levels of selective agent is a strong indication of transformation. All derived plants with selection pressure seemed morphologically normal, compared to the wild type plants. The regenerated putative transgenic plants showed complete blue coloration derived from GUS staining in leaf and root tissues, confirming the activity of the CaMV 35S promoter in these tissues of root chicory. PCR and RT-PCR analyses clearly showed integration of the T-DNA into genome of the regenerated root chicory plants (Figure 4). The developed shoot regeneration system in this experiment proved to be a potential system for future Agrobacterium-mediated gene transfer technology.

\section{Conclusion}

Different regeneration frequency among the different combinations of plant growth regulators indicated that regeneration was partially dependent upon the media sequence. Therefore, the appropriate media sequence could increase the efficiency of regeneration. Additionally the potentiality of different genotypes and explants are different for regenerablity. Using the suitable media with appropriate combination of plant growth regulators, high regenerable genotype and explant frequency of transformation could be maximised. 'Hera' and 'Melci' cultivars belonging to root chicory showed high regeneration ability either with cotyledon or leaf explant. However, leaf explant exhibited higher regenerablity. The differential ability of different cultivars may be due to 
differences in genetic background between the cultivars. Accordingly, the genotypes such as 'Hera' and 'Melci' with high regeneration ability may be used further for regeneration and transformation studies. From the result of Agrobacterium mediated-transformation, it can be concluded that the reported regeneration system is repeatable and can be easily used to develop new root chicory cultivars with desirable traits.

\section{ACKNOWLEDGEMENTS}

This work was supported financially by Institute for Agricultural and Fisheries Research- ILVO, Merelbeke, Belgium and Ministry of Science, Research and Technology of Iran.

\section{REFERENCES}

Abid M, Palms B, Derycke R, Tissier JP, Rambour S (1995). Transformation of chicory and expression of the bacterial uidA and nptll genes in the transgenic regenerants. J. Exp. Bot. 46:337-346.

Draper J, Scott R, Hamil J (1988). Transformation of dicotyledonous plant cells using the Ti plasmid of Agrobacterium tumefaciens and the Ri plasmid of $A$. rhizogenes. In: Draper $\mathrm{J}$, Scott $\mathrm{R}$, Armitage, $\mathrm{P}$, Walden $\mathrm{R}$ (eds). Plant genetic transformation and gene expression A laboratory manual. Blackwell Scientific Publications, Oxford, Edinburgh, Boston, Melbourne, pp. 69-190.

Deblaere R, Reynaerts A, Höfte H, Hernalsteens JP, Leemans J, Van Montagu M (1978). Vectors for cloning in plant cells. In: Wu R, Grossman L, (eds) Recombinant DNA, part D Methods in Enzymology, Academic Press, New York, 153: 277-292.

De Bruyn A, Alvarez AP, Sandra P, De Leenheer L (1992). Isolation and identification of B-D-fructofuranosyl-(2,1)-D-fructose, a product of enzymatic hydrolysis of the inulin from Cichorium intybus. Carbohydr. Res. 235:303-308.

De la Riva GA, Cabrera JG, Padrón RV, Pardo CA (1998). Agrobacterium tumefaciens: a natural tool for plant transformation. Electron. J. Biotechnol. 1:31.

De Leenheer L (1996). Production and use of inulin: Industrial reality with a promising future. In: Bekkum $\mathrm{H}$, Van HR, Voragen AGJ, (eds), Carbohydrates as Organic Raw Materials III, NY: VCH Publishers Inc. New York. pp. 67-92.

Frulleux F, Weyens G, Jacobs M (1997) Agrobacterium tumefaciensmediated transformation of shoot-buds of chicory. Plant. Cell. Tiss. 50:107-112

Harsh PB, Venkatesh RT, Chandrashekar A, Ravishankar GA (2001). Agrobacterium rhizogenes-mediated transformation of Witloof chicory- In vitro shoot regeneration and induction of flowering. Curr. Sci. India 80(1):83-87.

Jefferson RA (1987). Assaying chimeric genes in plants: the GUS gene fusion system. Plant. Mol. Biol. Rep. 5:387-405.

Kapila J, De Rycke R, Van Montagu M, Angenon G (1997). An Agrobacterium-mediated transient gene expression system for intact leaves. Plant. Sci. 122:101-108

Langer RHM, Hill GD, Mason K (1991). Agricultural Plants. Cambridge University Press, New York.

Larkin PJ, Scowcroft WR (1981). Somaclonal variation-a novel source of variability from cell cultures for plant improvement. Theor. Appl. Genet. 60:197-214

Lim HT, Park EJ, Lee JY, Chun IJ, An GH (2003). High plant regeneration and ectopic expression of OsMADS1 gene in root chicory (Cichorium intybus L. var. sativus). J. Plant. Biotechnol. 5(4):215-219.

Khatun M, Ali MH, Desamero NV (2003). Effect of genotype and culture media on callus formation and plant regeneration from mature seed scutella culture in rice. Plant. Tissue. Cult. 13(2):99-107.

Mineo L (1990). Plant tissue culture techniques. Tested studies in laboratory teachings Proc. ABLE, 11:151-174.

Muller E, Brown PTH, Hartke S, Lorz H (1990). DNA variation in tissueculture-derived rice plants. Theor. Appl. Genet. 80:673-679.

Murashige T, Skoog F (1962). A revised medium for rapid growth and bioassays with tobacco tissue cultures. Physiol. Plant. 15:473-497.

Nandagopal S, Ranjitha KBD (2006). Adenine sulphate induced high frequency shoot organogenesis in callus and in vitro flowering of Cichorium intybus L. cv. Focus - a potent medicinal plant. Acta Agric. Slov. 87(2):415-425

Nandagopal S, Ranjitha KBD (2007). Effectiveness of auxin induced in vitro root culture chicory. J. Cent. Eur. Agric. 8:73-80.

Nilsson U, Oste R, Jagerstad M, Birkhed D (1988). Cereal fructans: in vitro and in vivo studies on availability in rats and humans. J. Nutr. 118:1325-1330.

Park EJ, Lim HT (1999). Establishment of an efficient in vitro plant regeneration system in chicory (Cichorium intybus L. var. sativus). Acta Hortic. 483: 367-370.

Pazola Z (1987). The chemistry of chicory and chicory-product beverages. In: Clarke RJ, Macrae R (eds). Coffee Related Beverages, Elsevier Applied Science Publishers Ltd., New York, 5:19-57.

Pieron S, Watillon B (2001). Expression of a chimeric GUS gene construct as a tool to study nodule morphogenesis in chicory leaves. Plant Cell Tiss. Org. 66:159-165.

Rehman RU, Israr M, Srivastava PS, Bansal KC, Abdin MZ (2003). In vitro regeneration of witloof chicory (Cichorium intybus L.) from leaf explants and accumulation of esculin. In vitro Cell. Dev. Biol. Plant 39:142-146.

Rumessen JJ, Bode S, Hamberg O, Gudmand-Hoyer E (1990). Fructans of Jerusalem artichokes: intestinal transport, absorption, fermentation and influence on blood glucose, insulin and c-peptide responses in wealthy subjects. Am. J. Clin. Nutr. 52:675-681.

Silva RF (1996). Use of inulin as a natural texture modifier. Cereal Food World 41:769-794.

Sun LY, Gerard T, Charbonnier C, Tepfer D (1991). Modification of phenotype in Belgian endive (Cichorium intybus) through genetic transformation by Agrobacterium rhizogenes: conversion from biennial to annual flowering. Transgenic Res. 1:14-22.

Vancanneyt G, Schmidt R, Connor-Sanchez AO, Willmitzer L, RochaSosa M (1990). Construction of an intron-containing marker gene: splicing of intron in transgenic plants and its use in monitoring early events in Agrobacterium-mediated plant transformation. Mol. Gen. Genet. 220: 245-250.

Van Loo J, Coussement P, De Leenheer L, Hoebregs H, Smits G (1995). On the presence of inulin and oligofructose as natural ingredients in the Western diet. Crit. Rev. Food. Sci. Nutr. 35:525552.

Vermeulen A, Vaucheret H, Pautot V, Chupeau Y (1992). Agrobacteriu mediated transfer of a mutantArabidopsisacetolactate synthase gene confers resistance to chlorsulfuron in chicory (Cichorium intybus L.) Plant Cell. Rep. 11:243-247.

Vijn I, van Dijken A, Sprenger N, van Dun K, Weisbeek P, Wiemken A, Smeekens S (1997). Fructan of the inulin neoseries is synthesized in transgenic chicory plants (Cichorium intybus L.) harbouring onion (Allium cepa L.) fructan: fructan 6G-fructosyltransferase. Plant J., 11: 387-398.

Velayutham P, Ranjitha Kumari BD, Baskaran P (2007). An efficient in vitro plant regeneration system for Cichorium intybus $\mathrm{L}$. an important medicinal plant. J. Agric. Technol. 2:287-298.

Vervuet G, Holsters M, Teuchy H, Van Montagu M, Schell J (1975). Characterization of different plaque-forming and defective temperate phages in Agrobacterirrm strains. J. Gen. Virol. 26: 33-48.

Wagner GM, Gailing O (1996). The influence of different carbon sources on callus formation and shoot proliferation of chicory (Cichorium intybus L. var. sativum). Landbauforschung Volkenrode, 46:1-4.

Williams FMK, Davey MR, Power JB, Sidebottom C (2003). Chicory (Cichorium intybus L.) expressing the lol1 gene exhibits inhibition of ice recrystallisation. EUCARPIA Leafy Vegetables pp.137-142.

Yucesan B, Turker A, Gurel E (2007). TDZ-induced high frequency 
plant regeneration through multiple shoot formation in witloof chicory (Cichorium intybus L.). Plant Cell. Tiss. Org. 91(3):243-250.

Zhang DP, Golmirzaie A, Cipriani G (1997). Developing weevil resistance in sweetpotato with genetic transformation. In: International potato centre program report CIP, Lima, Peru, pp. 205210. 